\title{
Re-examining Mead
}

\author{
G.H. Mead on the 'Material Reproduction of Society'
}

FILIPE CARREIRA DA SILVA University of Lisbon, Portugal

\begin{abstract}
Despite decades of scholarship on G.H. Mead (1863-1931), we are still far from an adequate estimate of the full scope of his contributions. In this article, I examine the standard caricature that portraits Mead as an essentially idealist thinker, without much to say on the 'material conditions of reproduction' of modern industrialized societies. Focusing on Habermas's version of this interpretation, I try to show that if 'science and democracy' is a common theme amongst classical pragmatists, Mead is the only of these to whom we owe a communicative social theory that systematically connects science's problem-solving nature to democracy's deliberative character by means of social psychology that establishes the social nature of the human self. To suggest otherwise is to ignore that Mead's intellectual edifice is perhaps best described as a system in a state of flux, a structure that comprises three ever-evolving pillars: experimental science, social psychology, and democratic politics.
\end{abstract}

KEYWORDS democratic politics, Dewey, experimental science, Habermas, Mead, social psychology

Among sociologists all over the world, there is a widespread belief that 'Mead', the sociological classic, is an intellectual reference for his seminal ideas on the social character of human subjectivity. George Herbert Mead's book Mind, Self and Society (1997 [1934]) is read as if comprising the essential of his social psychological ideas, and is seen as a precursor for the symbolic interactionist sociological current that emerged in the United States in the 1960s as an alternative to Talcott Parsons's structural-functionalism. As a consequence, Mead's place in the sociological canon is essentially due to his referential analysis of the human self, with little or nothing to say about industrialization, war, politics. This article is aimed at showing that this 
image, however ingrained in the discipline's self-understanding, does not correspond to the truth.

This image of 'Mead' as a social psychologist solely concerned with the social nature of the human self is no more than a reflection of a long story of anachronisms, partial appropriations of his thought, and of the poor editorial situation of his writings. The history of the reception of Mead's ideas comprehends a number of interpretations that have reinforced this image. For instance, Mead's social theory of consciousness has been the inspirational motive of symbolic interactionism, a tradition of sociological thought responsible for a notable amount of empirical studies, and a recurrent presence in contemporary sociological treatises, most notably in Jürgen Habermas's The Theory of Communicative Action (1984 [1981], 1987 [1981]). In both cases, Mead is said to be responsible for original contributions on the micro-level of social interaction. As I will try to show, this sort of reading makes a crucial error: it overlooks the theoretical relevance of the insights Mead produced in his often neglected writings on democratic politics, warfare, international relations, and industrialization.

This last remark ties in with the way the structure of this article is conceived. I shall start by discussing Habermas's interpretation of Mead, arguably one of the most influential readings of Mead in contemporary social theory. In my view, the fundamental claim by Habermas that Mead had neglected the material aspects of modern, industrial societies is misleading and, to a certain extent, a consequence of Habermas's strategy of theory building. My next step will be to offer a historically minded reconstruction of Mead's social and political thinking. The lack of a complete edition of his writings left me with no choice but to undertake an archival research at the George Herbert Mead Papers, held at the Department of Special Collections at the Regenstein Library of the University of Chicago. Virtually all of Mead's major commentators have undertaken a certain amount of research there. ${ }^{1}$ In my case, in the course of a five-month stay I was able to unearth over 900 pages of unpublished materials, comprising both items written by Mead and transcripts of his classroom lectures.

In the first case, Mead's numerous manuscripts on questions concerning politics, war, and social reform were found to be particularly relevant. Overall, these items amount to approximately 250 pages. Together with the official records of Mead's participation in several organizations oriented to social reform activities, ${ }^{2}$ these unpublished materials - which exceed in length the published articles on the same subject - highlight the need to reassess the relative importance of this dimension within the framework of his intellectual edifice. Mead wrote extensively up to the very end of his career on democratic politics, social reform, and ethics. In these writings, he mobilizes the conceptual apparatus of his social psychology in order to put forth a scientific analysis of political and moral phenomena, and as such it is an integral part of his system of thought. Any reconstruction of Mead's intellectual enterprise that fails to acknowledge this fact understates an enduring and constitutive feature of his thinking, as well as one of 
his most relevant contributions to contemporary social and political theory. An additional claim I wish to make has to do with the differences between Mead and Dewey that have not yet been fully appreciated. A case in point refers to the social theoretical foundations of the pragmatists' moral and political theories. From this perspective, Mead's 'scientific social psychology' can be seen as the social theoretical foundations of the pragmatists' radical democratic theory that Dewey failed to provide.

\section{Habermas's Mead: The Cost of Becoming a Classic}

Habermas's appropriation of American pragmatism is especially noteworthy since the first generation of the Frankfurt School, in exile in the United States during the 1930s and 1940s, was particularly indifferent to the native currents of thought. Critical theorists such as Theodor Adorno and Max Horkheimer never seriously acknowledged either Parsons's 1937 The Structure of Social Action or John Dewey's political writings (Joas, 1993: 86). Unlike Hannah Arendt or Alfred Schutz, the relationship between the critical theorists associated with the Frankfurt School and the American social and political theorists was not a fruitful one. When seen in this light, Habermas's attempt to achieve a synthesis of the American and Frankfurt traditions is of an exceptional nature. In particular, his attempt to draw on pragmatist philosophy of science in the debate against positivism in the 1960s (Habermas, 1998 [1972]), his endeavors to reconcile Marxist democratic thought with American pragmatism's political insights (Habermas, 1986), and his paradigmatic shift from instrumental to communicative action and rationality (Habermas, 1984 [1981], 1987 [1981]) constitute long-term traits of his theoretical profile.

One has to admit that Habermas's central theoretical concern is not the history of science, nor even the history of ideas, but a specific kind of interpretative social science. His model of social science stands between a positivistic approach, which denies the methodological uniqueness of the social and human sciences, and a hermeneutical perspective, which questions the appropriateness of the notion of science when applied to the humanities. As Habermas puts it in On the Logic of the Social Sciences, this approach can be described as a 'hermeneutically enlightened and historically oriented functionalism' (1996a [1967]: 187). The basic idea is that of providing a normative reconstruction of the more advanced states of the learning processes of modern capitalist societies in the light of which systemic disturbances can be identified. This normative reconstruction is supposed to be grounded on a theory of language, whose first versions appeared in the early 1970s (see, for example, Habermas, 1970, 1991 [1976]), and was published in its most developed form in Habermas's magnum opus, The Theory of Communicative Action. With the publication of this two-volume book, Mead's image in sociology changes dramatically. He is no longer simply the first of the symbolic interactionists; ${ }^{3}$ he is one of the discipline's founding fathers, to whom we owe the paradigm shift from purposive to communicative action. The aim of this section is, then, to evaluate Habermas's 
appropriation and criticisms of Mead, ${ }^{4}$ namely his alleged neglect of the processes of 'material reproduction of society' and his lack of development of a theory of language. Whether or not there are good reasons to level such criticisms at Mead is what I wish to discuss in the following paragraphs.

The crucial turn in Habermas's argumentation, in the passage from the first to the second volume of this book, provides us with one of the most important episodes of the history of the reception of Mead's ideas into sociology. At the end of the first volume, Habermas discusses what he designates as critical theory aporias, whose most startling example was Adorno's Negative Dialectics (1973 [1966]). However, Habermas finds something positive in the difficulties met by the tradition of critique of rationalization ${ }^{5}$ when he observes that ' $[\mathrm{t}]$ here is something to be learned from these problems; indeed they furnish us with reasons for a change of paradigm within social theory', and concludes that ' $[\mathrm{w}]$ hereas the problematic of rationalization/reification lies along a "German" line of social-theoretical thought . . ., the paradigm change that interests me was prepared by George Herbert Mead and Émile Durkheim' (1984 [1981]: 366, 399).

In the second volume of The Theory of Communicative Action, Habermas begins his reconstruction of Mead's social psychology by focusing on the latter's phylogenetic account of the emergence of language. Mead conceives of the concept of 'conversation of gestures' as the evolutionary starting point that leads first to signal language and then to propositionally differentiated speech. Human language evolves firstly as signal languages, which mark the transition from gesture-mediated to symbolically mediated interaction, and secondly as the basis for normatively regulated action. There are, however, problems with Mead's account. According to Habermas, Mead's distinction between, on the one hand, symbolically mediated interaction and, on the other hand, linguistically mediated and normatively guided interaction is not adequate. In order to solve this difficulty, Habermas resorts to Wittgenstein's concept of rule. Habermas's point is that the transition from gesturemediated to symbolically mediated interaction involves the 'constitution of rulegoverned behavior, of behavior that can be explained in terms of an orientation to meaning conventions' (1987 [1981]: 16). In Habermas's view, Mead does not give the same weight to the three prelinguistic roots of the illocutionary power of speech acts. Mead did realize that language was the primary mechanism of socialization (which is linked to the emergence of norms and identities) and coordination of action (which is related to the world of perceptible and manipulable objects), but failed to inquire into the possibility of normative solidarity. As Habermas explains, Mead 'focuses on language as a medium for action coordination and for socialization, while leaving it largely unanalyzed as a medium for reaching understanding' (1987 [1981]: 27). Thus Habermas focuses his attention on Mead's ontogenetic account of the origin of personal identities and of objective perception.

The outcome of this analysis, arguably one of the most sophisticated readings of Mead's theory of ontogenesis, is the critical remark that Mead 'is moving in a circle' (Habermas, 1987 [1981]: 44). In Habermas's view, Mead tries to explain 
the phylogenetic transition from symbolically mediated to normatively guided interactions by resorting to a concept which figures only in his theory of ontogenesis, namely the 'generalized other'. It is in order to overcome this difficulty that Habermas then turns to Durkheim's theory of religion. This theoretical move, however, is not without problems. In particular, the way Habermas supplements Mead and Durkheim's proposals does not strike me as especially convincing. Although Mead did not develop systematically a phylogenetic explanation for the 'generalized other', if one takes into account Mead's conception of science and social psychology it is possible to trace back in the history of the human species the origin of such a concept. In fact, Mead reconstructs the evolution of the human species in terms of a constant and gradual increase of human rationality, based on the usage of vocal gestures that in the course of evolution acquire symbolic meanings, and that leads to, on the one hand, growing universality, abstraction, and impersonality (the Kantian features, as it were, of the generalized other, as well as the attitude of the research scientist and of the critical moral agent), and, on the other, an increasing trend towards individuality, authenticity, and originality (Mead's version of the Hegelian dialectic of the recognition). ${ }^{6}$ In other words, the evolutionary framework within which Mead develops what Habermas calls 'social individuation' contains the seeds for a phylogenetic account of the 'generalized other'.

When, some sixty pages later, Habermas returns to Mead, his purpose is to assess the extent to which Mead's contribution in fact supplements Durkheim's proposals. If Durkheim throws light on the phylogenetic origins of what Habermas designates as the 'linguistification of the sacred', that is, the transfer of the societal functions of cultural reproduction, social integration, and socialization from the religious realm to the structures of communicative action, Mead provides the explanation for these evolutionary trends from the perspective of socially individuated human beings. In other words, Mead is the first author to acknowledge the societal trend that Habermas calls the 'communicative rationalization of the lifeworld' (1987 [1981]: 107). However, Habermas still has some reservations concerning Mead's approach. The first is related to the formalist character of Mead's analysis of the societal processes comprised in the rationalization of the lifeworld. The second and more crucial reservation has to do with Mead's alleged 'idealism'. Habermas turns to functionalism in order to avoid the 'neglect of economics, warfare, and the struggle for political power' (1987 [1981]: 110) which Mead supposedly incurred given his 'idealistic' theoretical model. ${ }^{7}$ Habermas's reservation concerning the idealistic character of Mead's theory of society stems from his more general claim that Mead's sole contribution to contemporary social theory is a theory of the self that postulates the social character of human subjectivity. The point I wish to stress is that Mead's place in the canon was ultimately earned at the cost of the neglect of the two other pillars comprised within his system of thought, which I call the pillar of science and the pillar of democratic politics. The fundamental connection between science and democracy is thus forgotten. The remainder of this article will thus be devoted to the discussion of what Habermas accused 
Mead of having neglected - the pillar of politics - as well as, to a lesser extent, to the rest of the edifice, an intellectual structure whose thematic organization and systematic nature are ignored by most commentators. Some remarks are, therefore, due on the exact scope and nature of this intellectual structure.

The systematic nature of Mead's thinking is revealed as soon as one looks at the different ways he relates science, social psychology, and politics. To begin with, the psychological mechanism of 'taking the role of the other' can be seen operating in the attitude of the research scientist, in the attitude of the social actor (from both a phylogenetic and an ontogenetic viewpoint), and in the attitude of the citizen. On the other hand, there are different kinds of social environments within which the human self develops its activities by meeting problems and adapting to changing circumstances: the scientific community, the social group, and the political community. These pillars are linked in other aspects too. Given the priority of the scientific pillar, the two others can be seen as scientific approaches to specific problems, either the problem of the social origins of the individual self, or the problem of the moral and political organization of modern industrial societies. The relative importance of the second pillar is reflected in a distinctively social psychological approach that is mobilized to analyze, for instance, political phenomena. Finally, one can find a categorical conception of democracy in all layers of Mead's writings. The notion of a social order that is egalitarian, impartial, and open to participation and discussion pervades all aspects of his system of thought, from the inner forum of conversation to international relations between nation-states.

There are, then, multiple levels at which Mead's conceptions of science, social psychology, and politics intersect. What gives unity to this edifice is Mead's insistence on the communicative character of human rationality. While this is hardly a new insight for anyone minimally familiar to Mead's work, the fact remains that there is not even one single remark in all the secondary literature on him concerning his theoretical model of the various linguistic stages of development. As I will later show, Mead's remarks on the various 'moods of language' are not only closely related to the way he conceives of deliberative democracy and communicative ethics, but are also associated with his ontogenetic and phylogenetic theories.

\section{Mead: Radical Democracy and the Method of Science}

My aim in the following section is to discuss the theoretical domain Habermas accused Mead of neglecting, the pillar of politics. This is the realm where Mead's endorsement of the pragmatist orientation to connect theory and practice most clearly comes to the fore. As I will try to show, Mead wrote and published a significant amount of essays on democratic politics, communicative ethics, social reform, labour relations, immigration, and industrialization at the same time as he participated in various voluntary organizations and social movements. A second but related claim is that, in theoretical terms, Mead's conceptions of science and 
of social psychology are systematically connected to his moral and political thinking. In a nutshell, if the notion of 'reconstruction' is a central element of Mead's conception of science as a problem-solving activity as well as of his four-staged model of human action, the related idea of 'social and moral reconstruction' is the cornerstone of his political and moral thinking.

In his seminal Uncertain Victory, James Kloppenberg asserts that these ideas, 'moderate, meliorist, democratic, and sensitive to the possibility that no perfect reconciliation of liberty and equality can be attained, are the consequences of pragmatism for politics' (1986: 194). Mead's allegiance to this incremental, piecemeal reformism accompanies him throughout his life. The systematic nature of Mead's thought, a feature demoted by many commentators, allows him to mobilize similar formulations of the concept of 'reconstruction' in different problem-areas, slightly adjusting its meaning to the field in question. Either by claiming that '[1]ife is a process of continued reconstruction involved in the world as experienced' (Mead, 1972 [1936]: 292), or by asserting the need for social reconstruction, Mead is suggesting the same flexible and in-the-making worldview. What unites these different formulations of the concept of reconstruction is Mead's allegiance to the principles of the method of modern experimental science. Hence the logical priority of the pillar of science over the pillar of politics one finds in Mead's intellectual edifice.

From an early stage in his life, Mead develops a critical political consciousness, guided by radical democratic principles and oriented to the betterment of his community. In fact, even before Mead started his academic career he was already a concerned citizen with clear political allegiances. Unlike some commentators suggest, ${ }^{8}$ Mead was never a Republican, having wholeheartedly supported the Democrat President Woodrow Wilson. After a brief stay in Ann Arbor, Michigan, Mead eventually settled in Chicago, where he would be able to put into practice these projects he shared with his friend Henry Castle, who unfortunately would not live long enough to see it. Chicago was by that time a fast-growing metropolis that attracted millions of immigrants from Europe and was one of America's main poles of industrial activity, a city undergoing a process of profound social change and economic expansion. The risk of major social conflicts in such a modern industrial city was very clear in the minds of all of those who, like Mead, shared a belief in the possibilities of science to conduct human affairs. After being guaranteed an academic position at the University of Chicago in 1894, Mead emerged as an intellectual with unmistakable radical democratic sympathies.

Mead's civic engagement in reformist, voluntary activities was long and varied. From his support of and writings on the social settlement movement, ${ }^{9}$ to his involvement in the Immigrants' Protective League (which he helped to found in 1908), his participation on a citizens' committee established to solve the socalled 'garment strike' of 1910, and his long membership in the City Club of Chicago (which he joined in 1906), there are numerous examples of his belief that the 'study and work' of social and political reform should go hand in hand. While Mead was engaged in these voluntary activities he kept developing his theoretical 
position on 'intelligent social reconstruction'. As most first-generation modern theorists, Mead too considers the best remedy for the ailments of modernity to be the human activity that best represents that very modernity, that is, experimental science. From the perspective of contemporary social theorists, though, this can seem as a sign of overconfidence on the possibilities of science. As soon as one takes into account Mead's insistence on the internal connection between science and democracy, what looks like a possible naïveté emerges as a critical program aiming at articulating scientifically certain crucial social psychological insights and democratic political principles. Behind this program one finds a communicative theory of society that seeks to reconstruct the socio-linguistic roots of human rationality in both phylogenetic and ontogenetic terms.

This can be seen as early as in the 1899 essay 'The Working Hypothesis in Social Reform', where he rejects 'utopian' and 'doctrinaire' political doctrines, such as socialism, in favor of a scientifically grounded social reformism. As Mead asserts, in social reform 'what we have is a method and a control in application, not an ideal to work toward. As has been stated, this is the attitude of the scientist in the laboratory' (1899: 369). In two unpublished manuscripts written in this period, Mead addresses the conditions for intelligent social reconstruction in a period of rapid modernization. On one of those occasions, Mead discusses the social and political implications of the process of industrialization, wondering whether 'we can ever hold to any democracy consistently till we give every child a trained skill which shall guarantee him an economic and social status' (n.d.-b: 38). By giving priority to the need for an informed citizenry, on the part of the community, over the need for vocational training, on the part of the industrialists, Mead puts forth the radical democratic claim that without concrete material equality of conditions, the abstract theory of political rights is no more than an abstraction which benefits some at the expense of the many. In another unpublished manuscript, the sociological notion of 'social control' 10 emerges as the political expression of the pragmatists' ideological commitment to intelligent social reconstruction. Mead, believing that 'the most effective government is through public opinion' (n.d.-d: 7-8), posits in the social cooperation through the exchange of rational arguments by a cognitively competent and informed public opinion the solution for the value pluralism of modern mass societies. Building on this assumption, his endorsement of a theory of communicative ethics and a conception of deliberative democracy, which will be discussed later in this section, are but the logical corollary of his commitment to the ideal of uncoerced and informed dialogue. However, before I turn to Mead's conception of radical democracy, I wish to address his involvement in the single most important international event of his lifetime - the First World War.

\section{Mead and the War}

Indeed, the Great War constituted a challenge for the intellectuals and scientists of the beginning of the 20th century. It is fair to say that a whole generation of social 
thinkers, including sociology's classic figures, was offered the chance of superseding particularistic and non-scientific prejudices in the name of scientific objectivity and impartiality. Most of them, however, failed to meet that challenge (see, for example, Joas, 2003: 55-81). In my view, this is not true of Mead. His wartime personal correspondence and political writings, some of them still unpublished, show us a social scientist deeply concerned with the humanitarian consequences of war but willing to provide a scientific explanation for the causes and nature of that human tragedy. In this respect, Mead's social psychological explanation of the fusion of the two phases of the self in patriotic moments is of particular relevance. ${ }^{11}$

Mead's personal correspondence with Irene Tufts Mead, his daughter-inlaw, and son, Henry, right before and after America's entry into the war shows, at first, a profoundly distressed individual whose anti-militarism led to hope for a pacific solution, ${ }^{12}$ and later someone increasingly convinced of the fairness of the alliance of the values of democratic self-rule and labor rights against autocratic militarism. ${ }^{13}$ This change of opinion can also be identified in Mead's published writings. Following the evolution of the events in Europe from 1914 to 1917, Mead starts by expressing serious doubts about the war's rationale in the 1915 'The Psychological Basis of Internationalism'. ${ }^{14}$ For both personal and intellectual reasons, Mead followed the evolution of the war with great attention and growing concern. ${ }^{15}$ After the United States' entry into the war on April 6, 1917, in a series of newspaper articles published in the Chicago Herald in that summer, he shows a different understanding of the war. Reiterating his lifelong anti-militarism, Mead argues that the war had become a 'war for democracy' against the autocratic and militarist German regime (see Mead, 1917).

Furthermore, and refuting Habermas's claim that Mead had neglected the material reproduction of modern societies, here we see Mead applying his theoretical outlook (in a way that also expresses his personal values and ideological commitments) to the analysis of an example of the societal phenomenon of war. What is a purely theoretical account of the process of fusion of the two phases of the human self in Mind, Self and Society can be seen, in the above-mentioned 1915 article, being applied to the concrete example of patriotism, curiously enough an alluded example that Morris's editorial activity did not give us the chance of reading. ${ }^{16}$ Indeed, in that article, Mead starts his analysis of the war in Europe by taking note of its 'great spiritual dividends' (1915: 604). Arguing along similar lines as Simmel and Durkheim, ${ }^{17}$ he asserts that individual members of societies can fuse into self-conscious nations in moments of exceptional emotional intensity. Like a tide of national consciousness that sweeps across the body of citizens, these emotional moments are as intense as they are brief. When these moments occur, Mead contends, there is a fusion of the 'I' and the 'me': there is an absolute identification between the individual self and the social group. The fusion of the individual and the group is so complete that the individual can even lose himself 'in the whole group in some sense, and may attain the attitude in which he undergoes suffering and death for the common cause' (Mead, 1918: 598). 
Mead, however, is far from endorsing the irrationalist implications suggested by this psychological phenomenon. On the contrary, his proposed solution for settling international disputes comprises two elements drawn from his scientific social psychology. Firstly, rejecting James's assumption of a masculine fighting instinct, Mead asks why reformist activities should be seen as 'white-blooded' and 'feministic', when actually they are a 'vastly more intelligently conceived formulation of the same patriotic principles' (1915: 607). In Mead's view, social and political reform thus conceived is intrinsically internationalist since it gives priority to the interests of humankind over the interests of any particular state. Secondly, both in the notion of self-reflexivity as the elemental mechanism for the development of the self and in the idea of democratic self-rule as the basic condition for a meaningful group life, the same insight is suggested. Just as an individual depends on the existence of other human beings to exist, so the national identity and the very life of a political community are dependent on the existence of other nation-states. This is why Mead concludes this essay by stating that the solution for the problem of militarism, chief cause of the conflict, is of a psychological nature. It lies in a change of attitude on the part of the states of the Central Powers that would indicate the willingness to accept the fact that they are a but a part of a vaster community of nations; this way, Mead believes, they would be able to 'regard the states and the communities of which they are the instruments, as subject to and controlled by the life of the whole, not as potential enemies for whose assault each state must be forever on the watch' (1915: 607).

When Mead returns to these issues in the late 1920s, he still seeks to approach the problems of international relations and warfare from a scientific social psychological perspective. In 'National-Mindedness and International-Mindedness,' he reiterates his earlier account of the 'hostile impulse' in order to describe the social psychological instinct responsible for 'the spiritual exaltation of wartime patriotism' (1929: 393). There is, however, one crucial innovation in this later analysis. Language, as a rational cooperative activity, is seen as a prominent mechanism for the resolution of international conflicts: it is by means of intelligent deliberation that contending parties should resolve their disputes. In Mead's own words, over against the instinctive hostile impulse, one should resort to 'the power which language has conferred upon us, of not only seeing ourselves as others see us but also of addressing ourselves in terms of the common ideas and functions which an organized society makes possible' (1929: 395). Retaining the evolutionary perspective that characterizes his theory of phylogenesis, Mead argues that nationalism is a historically recent phenomenon by which men suddenly realized that they belonged to communities that transcended their families and clans. In this sense, 'national mindedness' is to be conceived of as a conversation with a 'generalized other', more general than previous forms of human association, but less general than the form idealized by Mead. As he puts it: 'Can we carry on a conversation in international terms?' (1997 [1934]: 271). According to Mead, the 'moral equivalent of war', to paraphrase James, is to be found in the socially acquired capacity for rational linguistic expression of ideas, 
rather than in some fundamental social impulse. It is a rationalist and internationalist solution that Mead proposes.

\section{Language, Science, and Democracy}

This said, Mead's contributions to contemporary social and political theory are not limited to his writings on international relations, industrialization, immigration, and other civic issues. In fact, his communicative theory of society comprises a normative conception of democracy and an ethical theory that deserve a closer scrutiny. What connects these two elements of Mead's political thinking is the ideal of a political community whose citizens are able to maintain social order by means of the exchange of rational arguments that leads to mutual understanding. I will thus devote the remainder of this article to the analysis of the socio-linguistic foundations of Mead's political and moral theory, the aspect of his thinking that most clearly distinguishes his contributions from Dewey's. Mead's discussion of the various 'moods of language', as far as I know a completely overlooked element of his thinking, can be found in a set of student notes taken by G.E.M. Shelburg in the winter quarter of 1927.18

I should start by noting that these notes differ significantly from those taken by W.T. Lillie in the winter quarter of 1928, a professional stenographer hired by Alvin Carus, from which Charles Morris constructed Mind, Self and Society. ${ }^{19}$ In the Shelburg notes, one finds a whole new perspective on language and self-consciousness from the one discussed in Mind, Self and Society. Firstly, we have the imperative mood, a form of communication originally associated with a situation where social relations were regulated through force and coercion. In the course of social evolution, the imperative mood came to be the expression of the socially binding nature of obligations and duties (Mead, 1982: 160). Following this initial form of language, and associated with the physiological development of the central nervous system, two other moods of language have emerged - the subjunctive, associated with deliberation, and the optative, related to decision-making situations. The individual self could thereby express to himself as to the others alternative courses of action, which imply that he enjoys a certain degree of autonomy. Seen as the most advanced stage of the evolutionary process of the human species, the indicative mood of language paves the way to the overcoming of the individual vs social dichotomy. In a situation where social relations were governed by superior force, the imperative mood of language expressed the non-existence of a 'generalized other' that could exert social control; this all changes when the subjunctive, optative, and indicative moods of language allow for the emergence of self-conscious individuals, more autonomous than their ancestors, yet members of their communities to an extent unknown in the history of the human species. The evolutionary character of the successive moods of language is reflected in the ontogenetic process of evolution too. As the most advanced moods of language emerge in the course of social evolution, the successive stages of psychological 
development show individuals increasingly capable of apprehending meanings in their fullest generality.

The specifically political implications of this line of argument are far-reaching. The evolution of language accompanies the social evolution from a stage where one commands and the other obeys or refuses to obey, to a stage where individuals are no longer 'forced to carry out the response by the social suggestion' (1982: 161), being able to select their courses of action, in an autonomous and cooperative fashion. Moreover, consciousness emerges only with this subjunctive mood of language for, as Mead explains, the central nervous system 'stands for the ability to present alternatives by introducing a temporal dimension into action. To get the different possibilities into the present situation, one can suggest the other alternatives. Here, then, is deliberation, conversation, an inner forum or council' (1982: 161). The outcome of such a deliberative and rational process is the emergence of an indicative 'mood of language', in which alternative courses of action are identified by the social actor. To carry out an act, however, the individual must take the attitude of the group given the conventional nature of language - 'one is always speaking to audiences or communities, expressing universals that are significant to others' (1982: 161).

In this light, both Mead's conception of deliberative democracy and his communicative ethics gain added significance. In the first case, any theory of democracy revolves around a certain notion of citizenship. However, this concept is treated only in passing in Mead's published political writings. To find his conception of citizenship one has to resort, once again, to his unpublished manuscripts. Indeed, in the unpublished essay 'How Can a Sense of Citizenship be Secured?' (n.d.-a), Mead introduces citizenship as the political correlate of the self's social character in a rather Aristotelian tone. The continued, committed, and disinterested exercise of the rights and duties associated with the membership in a political community is the condition for a truly democratic society. Only a society where all the citizens exercise their rights and duties diligently and to the full extent of their rational abilities meets Mead's communicative ideal of a free and democratic society. Furthermore, only if all particular interests are given equal attention do political decision-making processes express the 'common good'. Thus far, Mead's conception of citizenship, with its civic-republican emphasis on the virtues of democratic participation, is not that different from John Dewey's, his life-long friend. ${ }^{20}$ However, Mead supersedes Dewey's radical democratic conception when he, drawing a parallel between life in a social group and life in a political community, observes that, in both cases, individuals act in the context of institutions whose structural nature is beyond their consciousness. Only when conflicts occur do individuals, either as social actors or as political citizens, gain consciousness of the fundamental social values embodied in institutions like the family, the school, or the parliament. Arguing along similar lines to the Shelburg notes, Mead then goes on to suggest that we 'get hardly more immediate meaning out of the constant process of the evolution of social institutions than we do out of the processes of dialectical changes which take place in our mouths . . a great laws of speech' (n.d.-a: 10-11, italics added). 
Taking this last remark into account, it should not be difficult to understand Mead's insistence on the communicative nature of his ethical theory. Again, it is around the notion of 'reconstruction', only this time 'moral reconstruction', that Mead constructs his theory of moral problem-solving. As he explains in the 1923 article 'Scientific Method and the Moral Sciences', both the ethical ends and the means to attain them can be subject to 'restatement and reconstruction' by the 'intelligent method of science' (1923: 244). ${ }^{21}$ Mead's theory of solving moral problems, despite never having been explicitly connected to his analysis of the 'moods of language', shows, nonetheless, a communicative character, as well as some proceduralist and universalistic features. The proceduralism of Mead's ethics, heavily influenced by his conception of science, derives from its emphasis not on the definition of a determined final end that is supposed to motivate moral action (he rejects defining the 'common good'), but on the definition of the procedures of a democratic and experimental moral method. The universal character and the communicative nature of Mead's ethics are entwined points. Both the research scientist and the critical moral agent have to take into consideration all the relevant facts. The solution of moral problems lies in being able to have the wider perspective possible so that all the conflicting points of view, interests, or ends are fully appreciated. Since bearing in mind all the perspectives is ultimately a problem of communication, Mead's ethics are necessarily communicative: every part in conflict must be able to express his viewpoints in an intelligible way for all the others. Hence, his theory of ethics is universalistic given its orientation to the rational perspective of the 'generalized other', and, in particular, to the 'rational community that is represented in the so-called universe of discourse' (Mead, 1997 [1934]: 202).

In a similar way, Mead suggests that the experimental method of science and democratic politics are internally connected given their reliance upon the same communicative type of rationality. Both in a scientific discussion in a research laboratory and in a political discussion in a parliament, the human ability to communicate in a rational fashion is the basis upon which the coordination of the conduct of individuals, either as scientists or as citizens, is carried out. To the social scientist is reserved the function of analyzing these situations by reconstructing the 'great laws of speech' both from a phylogenetic and from an ontogenetic perspective. From this point of view, it is only natural that Mead is skeptical about a merely quantitative analysis of democratic politics. Much more important than the 'clumsy method of registering public sentiment which the ballot box affords in a democracy' (Mead, 1923: 244) are, to Mead as to Dewey, the continued and informed debates by a cognitively competent and civically engaged citizenry. In a book published shortly after Mead's article, The Public and Its Problems (1984 [1927]), Dewey subscribes to a similar position to the one argued by Mead. Dewey writes:

Majority rule, just as majority rule, is as foolish as its critics charge it with being. But it never is merely majority rule. ... The essential need, in other 
words, is the improvement of the methods and conditions of debate, discussion and persuasion. That is the problem of the public.

(1984 [1927]: 365)

This pragmatist understanding of democratic politics is of central importance for Habermas's discursive conception of deliberative democracy. Habermas acknowledges this fact in his latest major political work, Between Facts and Norms, where he quotes approvingly Dewey's words (see Habermas, 1996b [1992]: 304), but says nothing of Mead's writings on the same subject.

Habermas thus fails to see that the communicative nature of Mead's theory of society gains, in the field of democratic political theory, a deliberative tone. In my view, failing to see this amounts to failing to grasp the very core of Mead's intellectual system: the scientific reconstruction, both in the history of the human species and in the history of the child, of the communicative dimension of human rationality. This social theoretical contribution also helps one to distinguish Mead's work from Dewey's. Unlike Dewey, Mead consistently sought to develop a scientific approach to the problems of the 'social or moral order'. Such an approach makes use of the experimental method of science in order to provide a social psychological explanation of moral and political phenomena. Resorting to his social theory of the self, Mead claims that the content of moral acts can be universalized insofar as one recognizes their eminent social character. A moral end is reached only when an individual is able to identify his motive with the common good of the community in which he lives. The difference between good and evil stems from the social character of the self since a moral end is good when it leads to the realization of the individual as a social being. Social psychology can illuminate moral philosophical questions, Mead contends, for 'it is as social beings that we are moral beings'. ${ }^{22}$ This line of argument is a significant demonstration that Mead conceives of social psychology and moral philosophy as closely connected fields of research, much in accordance with my thesis that his thinking has a systematic nature. Moreover, in the basis of Mead's argument on the interconnectedness between the social and the moral orders there lies the scientific attitude of the research scientist. Granting the perspective of the scientist the status of a model of impartiality, impersonality, and objectivity, he suggests that moral conflicts can be resolved insofar as all values and interests are taken into consideration. This implies a process of reconstruction of the self, which becomes a larger self by assuming the attitude of the 'generalized other', which is also a moral reconstruction. Hence Mead's moral dictum, itself a reformulation of Kant's categorical imperative - 'One should act with reference to all the interests that are involved'. ${ }^{23}$ Mead's favored moral procedure is, then, an application of the procedure of modern experimental science to the problematic moral segment of the 'world that is there'.

The ultimate goal of a science of politics and morals is the resolution of concrete ethical problems. Exactly how this science is to be intertwined with a scientific theory of the psyche was something Mead felt the need to explain to his 
students in his lectures on social psychology. In fact, the social theoretical basis of Mead's moral and political thought can be grasped in scattered remarks throughout Mind, Self and Society. To begin with, insofar as Mead's conception of participative democracy is a specific kind of social cooperative activity, it is closely related to the mastery of a natural language (see Mead, 1997 [1934]: 267-8). At this point, it is instructive to recall C. Wright Mills's Sociology and Pragmatism (1966), where one can find a sharp criticism of the pragmatists' scientific approach to social reform and moral reconstruction. Mills points to the fact that a social theory of the mind was 'the mudsill of the liberal psychology of Dewey' (1966: 448). Without a sound social theory, the social and political reformist activities of the pragmatists lacked a legitimate theoretical basis. If this might be a fair critique of Dewey's social psychology - one that Mead (1994) himself was ready to make the fact remains, as Mills recognizes in the 'Postscript' to Sociology and Pragmatism, that his sociological analysis of pragmatism did not include an extensive treatment of Mead's social theory (1966: 464). It is my contention that if it did, Mills's judgment would not be so harsh on the pragmatists.

\section{Conclusions}

In this article, I have argued that Habermas's appropriation of Mead, though theoretically sophisticated, might nevertheless be criticized for emphasizing only those aspects which are immediately relevant for his theoretical strategy. In particular, Habermas's criticism of Mead supposed 'idealism' is not sensitive to the true scope and relevance of his contributions to contemporary social and political theory. While Mead does not make use of a functionalist systems theory to analyze politics, warfare, and the economic aspects of modernization, I contend that Habermas's critique of his 'idealism' is not warranted, for one fundamental reason. Behind Habermas's claim one finds his theoretical option to proceed 'reconstructively, that is, unhistorically' (1987 [1981]: 383). ${ }^{24}$ This is the reason why Habermas looks into the past in search for exemplary usages of his own ideas: such an anachronism entails, I argue, serious theoretical implications. For instance, one is not able to appreciate that the dynamic-systemic aspects of society - what Habermas calls the 'material reproduction of society' - can be analyzed by means of a theoretical perspective that transcends the idealist-materialist dichotomy. Such a theoretical perspective, first created by the classical pragmatists and now being developed by their contemporary heirs, ${ }^{25}$ points to a unitary conception of action underpinned by a radical democratic ideal of communication that is at least as promising as Habermas's attempt to reconcile a functionalist systems theory with a theory of action. In other words, a historical reconstruction of Mead not only shows that to charge him of 'idealism' is but a consequence of one's own theoretical agenda, but also that Mead and the other pragmatists have developed the fundamentals of a theory of human action that is as adequate to study large-scale social and economic phenomena as it is to analyze faceto-face interactions. 
I believe a historically minded reconstruction of a sociological classic can supplement, and even sometimes correct, presentist interpretations of the past. This is not to say that Habermas should be criticized for not taking into account all of Mead's published and unpublished papers. Rather, my contention is that Habermas's presentist interpretation, even if it allowed him to recognize some of Mead's contributions, thus granting him a place among sociology's founders, prevented him from acknowledging the full scope of his contributions. Pace Merton (1949), theory and history of theory are then but different faces of the same coin. The relevance of an author's contributions can be established only in a theoretical way; yet the factual accuracy of such a theoretical task can only benefit from a historically minded reconstruction of its subject-matter. In the case of Mead, as I tried to demonstrate, among his most relevant (and neglected) contributions to today's social and political theory is the notion that a deliberative kind of participatory democracy is internally linked to a conception of science as a puzzle-solving activity. As a matter of fact, most of the best current scholarship on deliberative democracy and pragmatism makes exactly this claim.

A second, related contention of the paper was to show the centrality of the category of 'public discourse' for Mead's social and political thought. Indeed, Mead's deliberative theory of democracy places its faith not on the skills of the professional party members, but on the wisdom of the informed layman. Mead's model of democracy is not centered on the state; on the contrary, it presupposes a pluralistic and decentralized set of political institutions of which the state is simply the one operating at the national level. Below the state, there are the municipal authorities, whose importance Mead never ceased to emphasize, and above the state there should be an international institutional body able to arbitrate and settle the conflicts between national states. At each level, the existence of an active public sphere is of pivotal importance: the denser the communicative network between the individual members, the more democratic and effective the influence of that sphere of political activity. It is in such an 'informed citizenry' that Mead finds the ultimate source of legitimacy of a constitutional democratic regime. When Mead speaks of 'institutionalized revolution', he is drawing the borders between the piecemeal reformism of the pragmatists and the revolutionary means of the socialists. Living at a time which would be later known as the Progressive Era, Mead embodied some of the intellectual traits of his generation. What he saw as the distinctive feature of the philosophical work of his friend Dewey, T.V. Smith, in accordance with my interpretation, identifies as the motto of Mead's own social philosophy - 'amelioration through understanding' (1931: 369).

Let us now elaborate a little further on Smith's happy formulation. Mead's social reformism, as I have tried to show, is based upon his scientific social psychology, whose central conceptual tool is the mechanism of 'taking the attitude of the other'. To 'understand', in Mead's view, means to be able to put oneself in another's shoes; hence, to 'ameliorate society through understanding' means to be able to creatively reconstruct the social and cultural setting where one lives by assuming the 
attitude of the 'generalized other'. Social criticism is, from this point of view, not only something legitimate for citizens to undertake, but also and fundamentally a major source of social progress and change. A consistent criticism of our own social and cultural horizon presupposes, therefore, a communicative type of rationality that implies an ideal set of claims. As Mead puts it, 'these larger patterns afford a basis for the criticism of existing conditions and in an even unconscious way tend to realize themselves in social conduct' (1930: 705-6). Social reconstruction is, then, the route open to everyone willing to apply the scientific method to moral and social problems. Science's practice of rational exchange of arguments between equals, in which all facts must be taken into consideration and subjected to empirical testing, and in which every solution is inescapably provisional, is the model upon which Mead draws to conceive of democracy. The cognitive and linguistic nature of his conception of democratic politics provides compelling evidence in support of this thesis. If 'science and democracy' is a common theme amongst classical pragmatists, it is to Mead that we owe the only communicative social theory that systematically connects science's problem-solving nature to democracy's deliberative character by means of social psychology that establishes the social nature of the human self. Such is one of Mead's seminal contributions to contemporary social and political theory.

From this vantage point, C. Wright Mills's aforementioned criticism that American pragmatism fails to develop a social theory that sustains its political proposals seems to be, at least when applied to Mead, unduly harsh. It is true that Mead never provided a fully developed account of such a theory. But the fact remains that the basic tenets of a social conception of the self were produced, and that Mead explicitly made use of this social psychological model in his political writings. The relevance of this social theoretical argument for political theory stems from its emphasis on language. The deliberative kind of democracy endorsed by Mead, Dewey, and other pragmatists is given, especially by Mead, a 'sociolinguistic foundation' that is of great interest from the point of view of his possible contributions to contemporary social and political theory.

In other words, if Dewey's political thought can be criticized for not being sustained by a social theory that provides a model of explanation of human action and rationality, the same criticism cannot be leveled at Mead. Among the classical pragmatists, it was Mead who developed in a more consistent fashion a social theoretical foundation for his moral and political theories. It would be an anachronism to suggest that Mead 'anticipated' by over fifty years the deliberative turn in democratic political theory. It would be an even greater error, though, not to recognize that his analysis of the late 1920s comprises the conceptual elements to which, already in the 1990s, political thinkers resorted to produce their deliberative proposals. This is precisely what intellectual history has to offer to social and political theory building: long-forgotten ideas that, if adequately integrated in contemporary social and political theory, are able offer us the possibility of engaging in dialogue with our predecessors about the best way to solve the problems we wish to tackle. 


\section{Notes}

With sincere appreciation I thank Donald Levine, Hans Joas, Patrick Baert, and Darin Weinberg for thoughtful and challenging comments on, or conversations about, earlier versions of this article, as well as for inspiration and support. I also wish to thank the JCS reviewer's insightful comments.

1. I am referring to David L. Miller, Hans Joas, Harold Orbach, Gary Alan Cook, and Andrew Feffer.

2. See the University of Chicago Settlement Board Minutes and Reports, held at the Mary McDowell and the University of Chicago Settlement Papers, and The City Club Bulletin, published by the City Club of Chicago and held at the Regenstein Library of the University of Chicago.

3. It is worth noting that authors like Gisela Hinkle claim Habermas's critical social theory 'invites symbolic interactionists to undertake a new reflection which recognizes and takes seriously cultural heterogeneity and the multiple rationalities of a modern global society, one in which rationality conceived communicatively is the topic of critical research' (Hinkle, 1992: 331).

4. However, Habermas's most detailed treatment of Mead to date is to be found in his book Postmetaphysical Thinking (1992 [1988]). In a chapter entitled 'Individuation through Socialization: On George Herbert Mead's Theory of Subjectivity,' Habermas addresses the problem of individuality throughout the history of philosophy, presenting Mead as the first author to have reconciled individuation with socialization.

5. A tradition inaugurated by Weber, and developed by Lukács and by the Frankfurt School.

6. For an account that also emphasizes Mead's attempt to reconcile Hegel and Kant, see Aboulafia (1995).

7. Joas similarly notes that Mead's 'works cover the entire spectrum ranging from the dialogue of significant gestures to complex scientific or public political discussions' (1991: 107).

8. Dmitri Shalin, possibly misled by the title of an early essay of Mead, contends that despite his 'admiration for Wilson, Mead would remain loyal to the Republican party throughout his life' (1988: 920). This is by no means a correct description of Mead's political allegiances. Mead's admiration for Wilson was not an oddity, but the very expression of his sympathy for the Democratic Party. As his personal correspondence shows, Mead never supported a single Republican presidential candidate; quite the contrary.

9. Social settlements first appeared in England in the 1870s, as a joint church-university initiative. What distinguishes a social settlement from other social institutions is the fact that its workers actually share their daily lives with the citizens they are supposed to help.

Once again, unpublished manuscripts reveal their importance. In effect, the most complete account of Mead's view on the social settlement movement is not the brief discussion one finds in 'The Social Settlement, Its Basis and Function' (1907-8), but the unpublished essay 'On the Role of Social Settlements' (n.d.-c), where he discusses at great length his views on this social movement. One of the very few analyses of Mead's views on the settlement movement is Cook (1993: 99-104); unfortunately, and even if this is one of the most historically minded studies of Mead to date, Cook's analysis it is solely based on the short published above-mentioned article.

10. Mead defines 'social control' as a form of self-criticism that, 'far from tending to crush out the human individual or to obliterate his self-conscious individuality, is, on the contrary, actually constitutive of and inextricably associated with that individuality' (1997 [1934]: 255). 
11. One of the very few texts devoted to this point is Campbell (1995).

12. '.. what America ought to insist upon is the right to continue her life in the international society, while she remains out of that war in which she has refused to join' (Mead to Irene Mead, February 18, 1917, Mead Papers, box 1, folder 14).

13. 'I have never felt so strongly the necessity of America's fighting as I do now. The democratic issue that we fight for should be made clear not only by the president but also by the people' (Mead to Henry Mead, March 7, 1918, Mead Papers, box 1, folder 15).

14. This essay was originally published in the journal Survey in 1915. I was able to determine the exact date this article was written because in a letter to his son Henry, dating from January 21, 1915, Mead makes the following remark: 'I have written an article on Militarism which I was asked to write for the Survey' (Mead Papers, box 1, folder 8). During my archival work at Chicago I managed to locate its original version. Wrongly filed as an unpublished paper, it was held in the Addenda, box 3, folder 1 , under the title of 'Militarism and Nationalism', and includes an unpublished handwritten conclusion.

15. Mead's son, Henry, had military training in the Chicago area in the second semester of 1917 and joined the war effort in early 1918. The correspondence between Mead and his son in this period can be found in Mead Papers, box 1, folder 9 .

16. Mead announces the discussion of the 'attitudes of religion, patriotism, and team work', but the selection of the student notes made by Morris includes only his discussion of the other two attitudes (see 1997 [1934]: 273). For an account of Mead's views on patriotism in that book, one has either to go back to an earlier section, namely to the analysis of the function performed by the sense of superiority for the realization of the self (see 1997 [1934]: 207-9), or to go forward to the discussion of social conflict in a later section (see 1997 [1934]: 306).

17. According to Joas, while Simmel conceives of war as a 'deeply moving existential experience of an ecstatic feeling of security that liberates our personality from old inhibitions', Durkheim, in his sociology of religion, describes 'collective effervescence' experiences as a 'group ecstasy that has the function of shaping identity and creating social bounds' (2003: 65). Oddly, Joas fails to extend this parallel to the case of Mead's thesis of the fusion of the ' $I$ ' and the 'me'.

18. This set of notes was edited and published by David Miller in The Individual and the Social Self (Mead, 1982). However, contrary to the indications he provides in the introduction to that book, these notes are not from the spring quarter of 1927 nor do they cover only sixty pages. They were actually taken by Shelburg in the winter quarter of that year, and run to over 100 pages (Mead, 1927). I will quote from the volume edited by Miller since it is available to the wider public, but I must say that his editorial work is far from being reliable.

19. These notes can be found in Mead Papers, box 2, folders 4-13. In the last page of the original copy of this transcript, one can read 'Reported by W.T. Lillie', which is, as Harold Orbach pointed out to me, the typical phraseology used by stenographers at that time. It is to Orbach's long years of archival research, which go back to the mid-1970s, that we owe the true story behind Mind, Self and Society.

20. For the most complete account of the civic republican nature of Chicago philosophical pragmatism, see Feffer (1993).

21. Such a connection between science and morals can already be seen in the earlier essays 'The Social Self', where Mead states for the first time the possibility of solving problematic moral situations by means of a creative rational moral reconstruction that supersedes the disintegrating moral conflicts, 
leading to moral growth (1913: 379), and 'The Psychology of Punitive Justice', where he equates moral growth with the advance that takes place 'in bringing to consciousness the larger social whole within which hostile attitudes pass over into self-assertions that are functional instead of destructive' (1918: 581).

22. Mead Papers, box 7, folder 4 .

23. Mead Papers, box 7, folder 4 .

24. According to Habermas, rational reconstruction is a pure form of theoretical knowledge that is generated within a reflexive attitude, and as such it abstracts itself from particular historical contexts. (See Habermas, 1998 [1972]: 377-80.)

25. The names of Robert Antonio (1989), Hans Joas (1996 [1992]), and Dmitri Shalin (1992) come to mind.

\section{References}

Aboulafia, Mitchell (1995) 'Habermas and Mead: On Universality and Individuality', Constellations 2: 94-113.

Adorno, T.W. (1973) Negative Dialectics, trans. E.B. Ashton. London: Routledge. (Orig. pub. 1966.)

Antonio, Robert (1989) 'The Normative Foundations of Emancipatory Theory: Evolutionary versus Pragmatic Perspectives', American Journal of Sociology 94: $721-48$.

Campbell, James (1995) 'Community without Fusion: Dewey, Mead, Tufts', pp. 56-71 in Robert Hollinger and David Depew (eds) Pragmatism. From Progressivism to Postmodernism. London: Praeger.

Cook, Gary Alan (1993) George Herbert Mead: The Making of a Social Pragmatist. Urbana: University of Illinois Press.

Dewey, John (1984) The Public and Its Problems, Vol. 2 of John Dewey: The Later Works: 1925-1927, ed. Jo Ann Boydston. Carbondale: Southern Illinois University Press. (Orig. pub. 1927.)

Feffer, Andrew (1993) The Chicago Pragmatists and American Progressivism. Ithaca, NY: Cornell University Press.

Habermas, Jürgen (1970) 'Towards a Theory of Communicative Competence', Inquiry 13: 360-76.

Habermas, Jürgen (1984) The Theory of Communicative Action: Reason and the Rationalization of Society, Vol. 1, trans. Thomas McCarthy. Cambridge: Polity. (Orig. pub. 1981.)

Habermas, Jürgen (1986) Autonomy and Solidarity, ed. Peter Dews. London: Verso.

Habermas, Jürgen (1987) The Theory of Communicative Action: Lifeworld and System: The Critique of Functionalist Reason, Vol. 2, trans. Thomas McCarthy. Cambridge: Polity. (Orig. pub. 1981.) 
Habermas, Jürgen (1991) Communication and the Evolution of Society, trans. Thomas McCarthy. Cambridge: Polity. (Orig. pub. 1976.)

Habermas, Jürgen (1992) Postmetaphysical Thinking: Philosophical Essays. Between Metaphysics and the Critique of Reason, trans. William Mark Hohengarten. Cambridge: Polity. (Orig. pub. 1988.)

Habermas, Jürgen (1996a) On the Logic of Social Sciences, trans. Shierry Weber Nicholsen and Jerry A. Stark. Cambridge, MA: MIT Press. (Orig. pub. 1967.)

Habermas, Jürgen (1996b) Between Facts and Norms: Contributions to a Discourse Theory of Law and Democracy, trans. William Rehg. Cambridge: Polity. (Orig. pub. 1992.)

Habermas, Jürgen (1998) Knowledge and Human Interests, trans. Jeremy Shapiro. Cambridge: Polity. (Orig. pub. 1972.)

Hinkle, Gisela (1992) 'Habermas, Mead, and Rationality', Symbolic Interaction 15: 315-31.

Joas, Hans (1991) 'The Unhappy Marriage of Hermeneutics and Functionalism', pp. 97-118 in Axel Honneth and Hans Joas (eds) Communicative Action: Essays on Jürgen Habermas's Theory of Communicative Action. Cambridge: Polity.

Joas, Hans (1993) Pragmatism and Social Theory. Chicago: University of Chicago Press.

Joas, Hans (1996) The Creativity of Action, trans. Jeremy Gaines and Paul Kleast. Cambridge: Polity. (Orig. pub. 1992.)

Joas, Hans (1997) G.H. Mead. A Contemporary Re-examination of his Thought, trans. Raymond Meyer. Cambridge, MA: MIT Press. (Orig. pub. 1985.)

Joas, Hans (2003) War and Modernity, trans. Rodney Livingstone. Cambridge: Polity.

Kloppenberg, James (1986) Uncertain Victory: Social Democracy and Progressivism in European and American Thought, 1870-1920. Oxford: Oxford University Press.

Mead, George Herbert (1899) 'The Working Hypothesis in Social Reform', American Journal of Sociology 5: 367-71.

Mead, George Herbert (1907-8) 'The Social Settlement, Its Basis and Function', University of Chicago Record 12: 108-10.

Mead, George Herbert (1913) 'The Social Self', Journal of Philosophy, Psychology and Scientific Methods 10: 374-80.

Mead, George Herbert (1915) 'The Psychological Bases of Internationalism', Survey 33: 604-7.

Mead, George Herbert (1917) 'America's Ideals and the War', Chicago Herald, August 3.

Mead, George Herbert (1918) 'The Psychology of Punitive Justice', American Journal of Sociology 23: 577-602. 
Mead, George Herbert (1923) 'Scientific Method and the Moral Sciences', International Journal of Ethics 33: 229-47.

Mead, George Herbert (1927) 'Social Psychology', unpublished manuscript (typescript of student notes by G.E.M. Shelburg, winter quarter). Box 3, folder 4, 105 pp. Mead Papers Archive, Department of Special Collections, Regenstein Library, University of Chicago.

Mead, George Herbert (1929) 'National-Mindedness and InternationalMindedness', International Journal of Ethics 39: 385-407.

Mead, George Herbert (1930) 'Cooley's Contribution to American Social Thought', American Journal of Sociology 35: 693-706.

Mead, George Herbert (1972) Movements of Thought of Nineteenth Century, ed. Merritt H. Moore. Chicago: University of Chicago Press. (Orig. pub. 1936.)

Mead, George Herbert (1982) The Individual and the Social Self: Unpublished Work of George Herbert Mead, ed. David L. Miller. Chicago: University of Chicago Press.

Mead, George Herbert (1994) 'George Herbert Mead: An Unpublished Essay Review of Dewey's Human Nature and Conduct', Journal of the History of the Behavioral Sciences 30: 374-9.

Mead, George Herbert (1997) Mind, Self and Society from the Standpoint of Social Behaviorist, ed. Charles Morris. Chicago: University of Chicago Press. (Orig. pub. 1934.)

Mead, George Herbert (n.d.-a) 'How Can a Sense of Citizenship Be Secured?', unpublished manuscript. Addenda, box 2, folder 3, 11 pp. Mead Papers Archive, Department of Special Collections, Regenstein Library, University of Chicago.

Mead, George Herbert (n.d.-b) 'On the Effects of Industrialization', unpublished manuscript. Addenda, box 3, folder 14, 40 pp. Mead Papers Archive, Department of Special Collections, Regenstein Library, University of Chicago.

Mead, George Herbert (n.d.-c) 'On the Role of Social Settlements', unpublished manuscript. Addenda, box 3, folder 24, 12 pp. Mead Papers Archive, Department of Special Collections, Regenstein Library, University of Chicago.

Mead, George Herbert (n.d.-d) 'On the State and Social Control', unpublished manuscript (written after April 6, 1917). Addenda, box 3, folder 26, 8 pp. Mead Papers Archive, Department of Special Collections, Regenstein Library, University of Chicago.

Merton, Robert (1949) 'On the History and Systematics of Sociological Theory', pp. 1-37 in Robert Merton (ed.) On Theoretical Sociology. New York: Free Press.

Mills, C. Wright (1966) Sociology and Pragmatism, ed. Irving Horowitz. New York: Paine-Whitman. 
Shalin, Dmitri (1988) 'G.H. Mead, Socialism, and the Progressive Agenda', American Journal of Sociology 93: 913-51.

Shalin, Dmitri (1992) 'Critical Theory and the Pragmatist Challenge', American Journal of Sociology 98: 237-79.

Smith, T.V. (1931) 'The Social Philosophy of George Herbert Mead', American Journal of Sociology 37: 368-85.

Filipe Carreira da Silva is a research fellow at the Institute of Social Sciences of the University of Lisbon, and a senior member at Wolfson College, Cambridge. He is the author of several articles and books on classical and contemporary sociological theories, including G.H. Mead: A Critical Introduction (Polity, 2007).

Address: Institute of Social Sciences, University of Lisbon, Av. Anibal Bettencourt, 9, 1600-189 Lisboa, Portugal. [email: fcs23@ics.ul.pt] 